\title{
International Scaling of Sustainability Continuing Professional Development for In-Service Teachers
}

\author{
Erin Redman ${ }^{1 *}$, Cliona Murphy², Yasmany Mancilla3 ${ }^{3}$, Ben Mallon², Lydia Kater-Wettstaedt ${ }^{4}$, Matthias \\ Barth $^{4}$, Maria Gabriela Ortiz ${ }^{3}$, Greg Smith², Orla Kelly²
}

\author{
1 University of Wisconsin-Stevens Point, UNITED STATES \\ 2 Dublin City University, IRELAND \\ 3 Tecnologico de Monterrey, MEXICO \\ ${ }^{4}$ Leuphana University Lüneburg, GERMANY \\ *Corresponding Author: eredman@uwsp.edu
}

Citation: Redman, E., Murphy, C., Mancilla, Y., Mallon, B., Kater-Wettstaedt, L., Barth, M., Ortiz M. G., Smith, G., \& Kelly, O. (2021). International scaling of sustainability continuing professional development for in-service teachers. Interdisciplinary Journal of Environmental and Science Education, 17(3), e2243. https://doi.org/10.21601/ijese/10936

\begin{tabular}{|c|c|}
\hline ARTICLE INFO & ABSTRACT \\
\hline eceived: & Continuing professional development (CPD) offers a strong opportunity to transform schools quickly \\
\hline 25 January 2021 & enough to support today's s \\
\hline & $\begin{array}{l}\text { sustainability solutions. While there have been some efforts in these directions, so far attempts have } \\
\text { not been made to demonstrate whether these approaches to sustainability CPD can be scaled up }\end{array}$ \\
\hline Accepted: & internationally to the level necessary to meet the need to integrate sustainability across subjects and \\
\hline 1 May 2021 & grade levels. Through this multi-national collaboration, we shared a model and implemented it across \\
\hline & $\begin{array}{l}\text { three very different contexts. The results of this two year project are reported and the important } \\
\text { contextual factors for the competence development of teachers are identified. The model utilized } \\
\text { here demonstrated success despite significant barriers at each implementation site. We identify } \\
\text { three universal features that will create transformative sustainability CPDs: 1) Sufficient contact } \\
\text { hours 2) Solutions not problems and 3) Competencies not content. }\end{array}$ \\
\hline
\end{tabular}

Keywords: sustainability education, continuing professional development, in-service, 17 scaling solutions, education for sustainable development

\section{INTRODUCTION}

The needed transformations towards sustainability require that teachers understand sustainability challenges and can effectively engage their students in education for sustainable development (Frisk \& Larson, 2011; Vare et al., 2019). Primary and secondary schools are formative environments for building the capacity of future generations to grapple with complex sustainability challenges and develop solutions to issues such as global health, social justice, poverty and economic disparities, extreme weather events and species extinctions. Programs focused on teacher education for sustainability predominantly refer to the education of undergraduate, university students (e.g., pre-service teachers) (Archambault,
Hartwell, Frisk, \& Hale, 2012; Ferreira, Ryan, \& Tilbury, 2006; Nousheen, Zai, Waseem, \& Khan, 2020; Murphy \& Smith, 2012; Bürgener \& Barth, 2018).

Although sustainability programs are primarily targeting pre-service teachers, research on educational change has found that pre-service teachers are more likely to adopt the practices of their new schools, rather than changing the educational approaches of their schools or colleagues (Popova, Evans, Breeding, \& Arancibia, 2018). This leaves a significant gap between the desire to integrate ESD in primary and secondary schools today and the actual implementation of sustainability activities in schools. Consequently, the needs of 
teachers already working in schools (e.g., in-service teachers) need to be addressed, as they are the experts for their school, their colleagues, their environment and their students and knowledge about the system is a necessary pre-condition to implement new practices and motivate and convince others to engage (Biasutti, Concina, \& Frate, 2019).

Many researchers have found that the practical implications and relevance of ESD is not clear for the education professionals that are often expected to adopt this approach into their curriculum and practice (Redman et al., 2018; Vare et al., 2019). Complex sustainability issues, such as climate change and globalisation, require that teachers understand different cultural perspectives and can negotiate different points of view regarding critical $21^{\text {st }}$ century challenges (Biasutti et al., 2019; Plutzer et al., 2014). Adequate professional development could be a strong support to address these needs and implementing effective ESD in school systems. It has the potential to qualify in-service teachers as leaders of learning and educational change. Continuing professional development (CPD) programs provide opportunities for teachers to engage with novel pedagogies and have been suggested as a key mechanism for improving teacher self-efficacy ( Redman, Wiek, Redman, 2018; Murphy, Smith, Mallon, \& Redman, 2020). While there is great potential for creating positive change through CPD, most programs fail to engage teachers in tangible and interactive ways, hindering translation to new classroom practices and curricula. A recent review of CPD programs found that most (over 90\%) are still one-off, stand-alone workshops that are overly theoretical and use outdated 'sit and get' methodologies (Darling-Hammond, Wei, Andree, Richardson, \& Orphanos, 2009; Popova, Evans, \& Arancibia, 2016). In response to the shortcomings of one-off CPD programs, education and sustainability scholars have been developing, piloting, and evaluating long-term, intensive, real-world, hands-on approaches to CPD (Murphy, Smith, Varley, \& Razı, 2015; Redman et al., 2018). One such program was created by sustainability scholars at Arizona State University and piloted across the United States. Some key features of this CPD is that teachers apply in teams, co-develop and implement school-wide projects, and collaborate with sustainability leaders in the community to demonstrate sustainability solutions through real-world opportunities (Redman et al., 2018).

While the model laid out in Redman et al. (2018) showed promise, the question remained whether it points towards a generalizable, scalable approach to sustainability CPD. The urgency of our sustainability challenges and the delay between education and action means that successful and impactful approaches to sustainability CPD, addressing the scale and scope of the needs of teachers, need to be implemented quickly and at scale. But transferring and scaling programs which were successful in one particular time and context is a challenging and fraught enterprise, historically littered with failure (Rogers, 2003). This paper describes a two-year effort to create and implement an internationally scalable model for Sustainability CPD and reports on its impact. The CPD program was implemented in Germany, Mexico, and Ireland. All the CPD facilitators were based in local universities. In Mexico and Germany partnerships with the local governments were forged and the local municipalities took the lead on teacher recruitment, which meant that the partner organizations contacted the schools, rather than the CPD facilitors. In Ireland, the CPD facilitators contacted administrators at dozens of primary schools to recruit teachers. In each location, teachers were provided with meals, stipends, and certified professional development hours. This project sought to understand the aspects of sustainability CPD that can be scaled internationally, while also differentiating the scalable features from the contextspecific, place-based aspects. To evaluate the CPD impact and effectiveness, the team employed a mixed methods approach, gathering the experiences and perspectives of those teachers participating in the CPD. The research team undertook a series of semistructured interviews with teachers that participated in the 2-year CPD programme as implemented in Germany, Mexico and Ireland. These interviews explored what actions were taken in the curriculum and on campus to advance sustainability and were supplemented by pre- and post-program surveys, which explored any changes in teachers' reported levels of efficacy in teaching ESD in their classrooms.

\section{BACKGROUND}

In 2017 the Global Consortium for Sustainability Outcomes (GCSO) awarded funding to the project Sustainability Education: Continuing Professional Development for School Teachers and Faculty, a joint initiative between Arizona State University (ASU), Dublin City University (DCU), Hong Kong University of Science and Technology (HKUST), the Instituto Tecnológico y de Estudios Superiores de Monterrey (ITESM), and Leuphana University Lüneburg. This collaboration was able to bring together a group of leading scholars and practitioners of sustainability education in a joint effort to design and simultaneously implement a scalable, generalizable model for sustainability CPD. Implementation took place in three countries (Germany, Ireland, and Mexico), with 108 in-service teachers participating. 
The context and local teams of implementers are briefly described.

\section{Ireland: Dublin City University}

The team from DCU brought expertise and experience in implementing professional development focused on science and citizenship education with in-service teachers as well as with pre-service teachers on undergraduate and graduate programs. The lead implementers on this team were three associate professors in Science Education and one post-doctoral scholar. Three of the collaborating faculty had been practicing K-12 teachers prior to working in higher education. The Irish primary science curriculum (DES, 1999) emphasizes an inquiry-based approach to teaching and learning science that is grounded in a social constructivist framework. The curriculum highlights the importance of providing students with opportunities to develop scientific concepts and skills through applying skills typically used by scientists. The content of the Irish primary science curriculum is amenable to the integration of sustainable development issues. However, despite evidence that sustainability issues can be integrated across the curriculum (Ruane, Horgan \& Cremin, 1999; McGarr, 2010; NCCA, 2006), this is rarely being done for a variety of reasons (Bryan \& Bracken, 2011; McCormack \& O'Flaherty, 2010). Inquiry-based science education was the entry point for the teachers and CPD implementers to begin their conversations on sustainability.

\section{Mexico: Instituto Tecnológico y de Estudios} Superiores de Monterrey

ITESM is a private technical university located in Monterrey, Mexico. On this project, three professors from the School of Engineering and Sciences were the lead CPD implementers; as well as a project specialist, a biologist and a doctoral student, and two undergraduate students of the degree program of Engineering in Sustainable Development. This team with its engineering focus had a strong background in the environmental and technical sciences and brought that strong STEM perspective with them to the sustainability CPD. In addition, the context for sustainability for Mexican teachers is environmental science. The local support for that program from the Santa Catarina (local municipality) government was based on the interest of the coordinator of the environmental agenda, which is why the environmental aspects of sustainability were the focus of their approaches. The environmental tailoring doesn't fully encompass the holistic array of sustainability, however, the engineering faculty created and delivered innovative science education curriculum and pedagogies to teachers and ultimately classrooms.

\section{Germany: Leuphana University of Luneburg}

The team at Leuphana brought in their expertise from undergraduate and graduate programs in teacher education in which education for sustainability is fully implemented in their preservice curricula. The team of implementers consisted of an advising faculty member, a postdoctoral scholar, and a PhD student. In Germany, each state has their own education governmental department and in Lower Saxony, the state in which this CPD was conducted, sustainability was integrated as one of the overarching learning domains in the latest curriculum reform. However, it was not specified for the different subjects, which means that there is no clear distribution of responsibility to systematically implement ESD in the teaching practice. Teachers in Lower Saxony are presented with opportunities for CPD. In general, participation is obligatory, but it is not specified in frequency or hours, and no extrinsic incentives are in place. Therefore, it could happen that teachers go their entire careers with participating in only few CPD. Similar to Ireland and Mexico, the teachers and facilitators gravitated towards environmental aspects of sustainability, in a large part due to the long history of environmental education in Germany.

\section{DESIGNING A SCALABLE MODEL FOR SUSTAINABILITY CPD}

Via a series of virtual meetings, culminating in an in-person workshop, the international team of experts crafted a shared framework for applying sustainability CPD across multiple, diverse contexts. This drew heavily on research which has identified some key characteristics for successful CPDs including active learning, opportunities for teachers to engage in leadership roles, extended duration including initial face-to-face training, collective participation, and administrative buy-in (Desimone, Porter, Garet, Yoon, \& Birman, 2002; Garet, Porter, Desimone, Birman, \& Yoon, 2001; Murphy et al., 2015). In addition, linking participation in CPD to incentives for the teachers, such as promotion or salary implications, is associated with positive outcomes (Popova et al., 2018). While many of these best practices for CPD are applicable to a wide range of subjects; there are some practices which the team identified as particularly critical to sustainability programs.

First, sustainability is dynamic, so the program needs to go beyond providing and reviewing a 'handbook' or 'curriculum guide.' Rather sustainability CPD should focus on targeting critical 
knowledge, skills, values, and attitudes that enable the learner to understand and interpret the changing scene of sustainability (de Haan, 2006). In this sense, sustainability CPD is meant to target the teachers as adult learners and build their competence in sustainability, rather than viewing teachers as purveyors of activities to their students. Second, sustainability education is about more than just learning, or enhanced knowledge, it involves empowering the learner to take action and create positive change in the real world (Almers, 2013; Frisk \& Larson, 2011; Vare et al., 2019). Many researchers have found that when sustainability programs focus on global problems, students can feel disempowered and can even emotionally distance themselves from the material (Boone, 2015; Frisk \& Larson, 2011), therefore sustainability CPD needs to enable teachers to take these emotional, motivational challenges into account and to include locally and for student relevant challenges and actionable solutions.

\section{General Features}

Using the model described in Redman et al. (2018) and place-based experiences as the starting point the team agreed on five broad principles, that were applicable to sustainability CPD regardless of the context.

1. Teachers attend in teams (2 or more teachers from a school) so that organizational change is fostered and that barriers associated with oneperson leading school projects would be overcome. Participation of teams is a greater investment and thus commitment of schools which in turn would make teachers participation more visible and acknowledged in their respective school.

2. The CPD is long-term and intensive, including over 50-hours of face-to-face workshops over the course of three to six months. This intensity allows for deeper learning on sustainability and the duration enables teachers to translate their knowledge into practice in between workshop sessions.

3. The program targets the development of key sustainability competencies for the teachers, rather than focusing on a thematic topic or subject. Through a competencies-based approach, the concept of sustainability could be integrated into visual arts, history, mathematics, science, literature, philosophy, and many other curriculum areas. The key competencies on which the CPD focused included: systems thinking; future thinking; values thinking; strategic action; and, stakeholder engagement. In taking future thinking as an example for interdisciplinary learning, in a history class one could talk about path dependency based on historical context (e.g., the treatment of black people in America), whereas in art students could draw or paint an image related to a vision for sustainability futures, and in science they could present cases for responsible innovation of biotechnology for future sustainability innovations.

4. Teachers connect with local and regional sustainability leaders through field trips and guest speakers. Through these experiences, teachers see, touch, and feel sustainability in action and also create a network of sustainability leaders that can help support as they launch their sustainability initiatives. It was emphasized that the sustainability field trips and guest speakers would represent a holistic view of sustainability, including art, social justice, civic engagement, community leadership, and social entrepreneurialism.

5. Each team of teachers work together to develop and implement a school project, with small seed funding provided to each school (funded by GCSO). Throughout the professional development the teachers were to envision what a sustainable school looks like and how they can be part of the process in leading the transition. The sustainability project was the first step on this envisioned sustainability trajectory, with other milestones discussed on the path towards sustainability.

\section{Transmission-Translation-Transformation (3T) Model}

Implementing this international program, with an emphasis on locally relevant content was intentional and is necessary for empowering teachers and students to act at where they live, teach, and learn (feature 4 above). An example of an aspect with huge variability between the CPD implementation sites was the timing and frequency of face-to-face workshops (e.g., after school for 2-hours or a weekend retreat for 8 hours). Therefore, a generic framework of transmission-translationtransformation was proposed to individually structure each CPD (Figure 1), with variable hours during and between each phase.

During the transmission phase, the CPD facilitators engaged the teachers in hands-on lessons that were prepared for primary school students and ready to be used by the teachers in their classrooms as-is. These activities were introductory lessons targeted for primary school learners and shared with the teachers. The transmission phase focused on providing teachers with the opportunity to explore existing resources and supporting the delivery of sustainability-related activities and lessons that are ready for primary school learners. As part of the transmission phase, they were asked to implement one activity and reflect on the experience.

In the translation phase, the focus was on more complex sustainability issues that would equip 


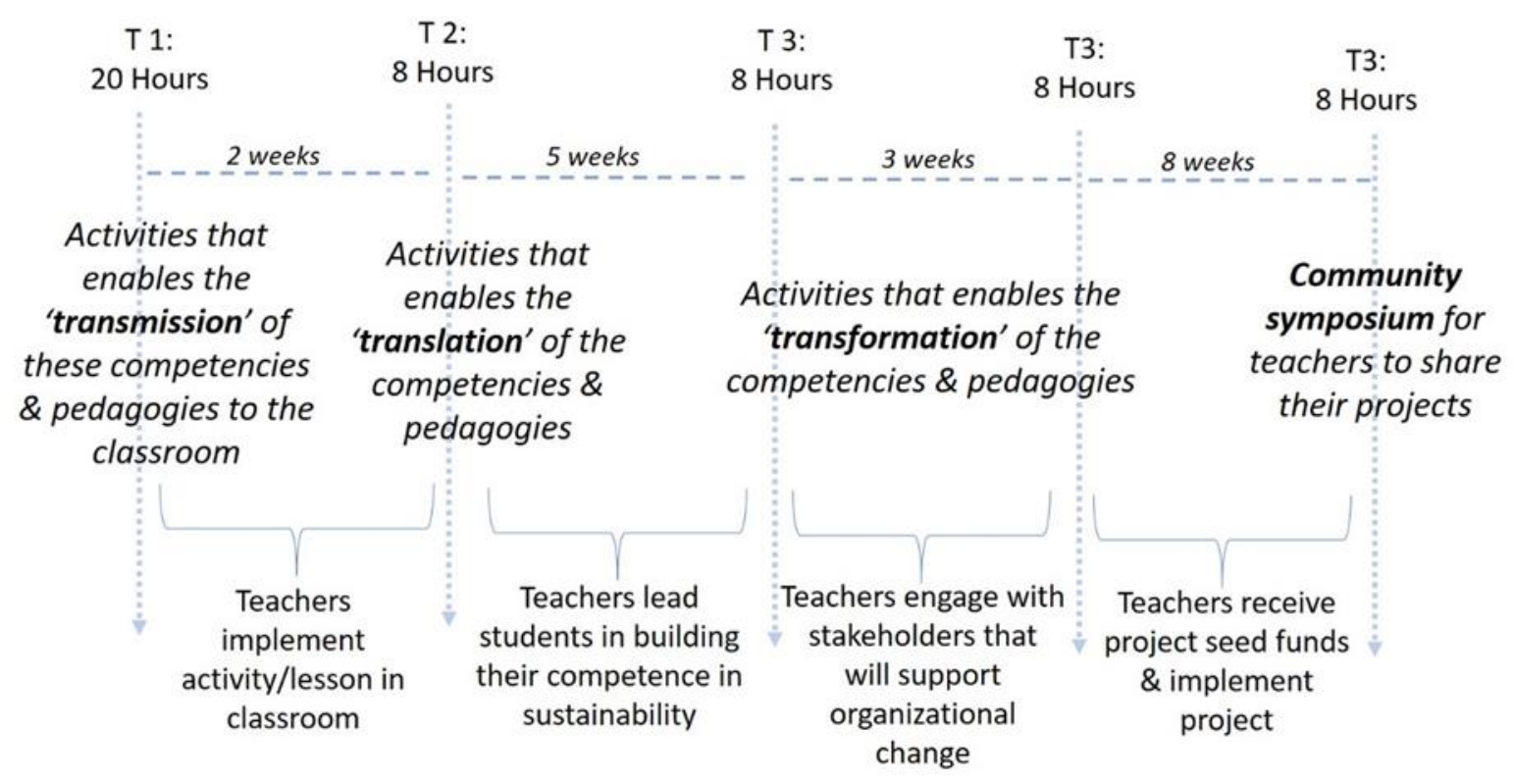

Figure 1. Timing and duration of 3T Model

teachers with a deeper knowledge and skill set. The translation phase focused on engaging the adult learner (the teacher) in complex sustainability issues, through a series of activities offering a deep engagement with sustainability competencies. These issues, such as urban resilience and climate change adaptation, are presented in their full complexity, and are targeted for the teachers as adult-learners and leaders in the classroom. With this deeper understanding, it was anticipated that the teachers would have the knowledge and skills to translate these complex issues into their classroom practice in an age-appropriate and pedagogically sound manner. Going beyond surface knowledge of sustainability during the translation phase is a critical part of preparing teachers to bring an ever-changing array of sustainability topics into the classroom in the future.

During the transformation phase, teachers are expected to integrate the knowledge and skills gleaned over the last six months to develop a vision for sustainability in their schools and to execute a project that would put them on a path towards that vision. The transformation phase largely happens within the teachers' schools and classrooms, as they develop and implement sustainability-related action plans with school stakeholders. The community symposium is an event that recognizes the hard work of the teachers and children and engages the school community in the sustainability projects. It is a critical part of positioning the teachers as leaders in sustainability and supporting organizational change for sustainability across the school. It is also an opportunity to reach out for a broader audience and a building block for network activities.

\section{Pre-program Differences}

Due to the long-term program design, we were able to adjust to the teachers' specific needs throughout the program to address questions they had while implementing activities during the transmission phase, for example. However, prior to the program starting, it was necessary to evaluate the teachers' pre-program knowledge, skills, confidence, and interests, to develop a CPD programme that would be centered on teachers' individual knowledge and competencies. Teachers were asked to take a preprogram survey with questions about their knowledge, confidence, experience, and skills in educating for sustainability. Whilst recognizing the significant differences in participating teachers in each country, attributed to the differing professional development systems in each country, this survey revealed many differences between the countries The teachers in Germany had significantly more confidence in their ability to educate for sustainability and reported that they currently frequently teach sustainability. As you can see from Table 1 (below), 100\% of the teachers in Germany indicated that they either frequently or occasionally teach about sustainability In contrast, almost $40 \%$ of teachers in Mexico and 61\% of teachers in Ireland indicated that they either were not sure whether they 
Table 1. "Have you taught a sustainability lesson in the past?"

\begin{tabular}{llllll}
\hline $\begin{array}{l}\text { Country (No of } \\
\text { participants) }\end{array}$ & $\begin{array}{l}\text { Yes, I frequently } \\
\text { teach } \\
\text { sustainability }\end{array}$ & $\begin{array}{l}\text { Ieccasionally } \\
\text { teach } \\
\text { sustainability }\end{array}$ & $\begin{array}{l}\text { Yes, one-time I } \\
\text { taught a lesson } \\
\text { on sustainability }\end{array}$ & $\begin{array}{l}\text { Maybe, although not exactly } \\
\text { sure }\end{array}$ & $\begin{array}{l}\text { No, I have never } \\
\text { taught a lesson } \\
\text { on sustainability }\end{array}$ \\
\hline Mexico (59) & $22 \%$ & $14 \%$ & $17 \%$ & $19 \%$ & $29 \%$ \\
Ireland (28) & $4 \%$ & $18 \%$ & $18 \%$ & $50 \%$ & $11 \%$ \\
Germany (7) & $57 \%$ & $43 \%$ & $0 \%$ & $0 \%$ & $0 \%$ \\
\hline
\end{tabular}

Table 2. Percentage who somewhat or strongly agree with the following statements

\begin{tabular}{lllll}
\hline Country & $\begin{array}{l}\text { I feel confident } \\
\text { sustainability }(\mathrm{n})\end{array}$ & to teach about & $\begin{array}{l}\text { I have sufficient knowledge to teach about sustainability } \\
(\mathrm{n})\end{array}$ \\
\hline Mexico & $54 \%(59)$ & $32 \%(59)$ \\
Ireland & $29 \%(28)$ & $0 \%(28)$ \\
Germany & $100 \%(7)$ & $85 \%(7)$ \\
\hline
\end{tabular}

had or never have taught a lesson on sustainability in the past. Given the relatively small number of teachers that participated in Germany, it is possible that the high knowledge and engagement in sustainability prior to the CPD is result of selfselection, meaning that teachers that choose to be in the CPD did so due to a long-standing commitment to educating for sustainability.

In further investigating how comfortable and familiar teachers were (prior to the program) with educating for sustainability, the survey asked the teachers to self-rate their confidence and knowledge. Again, the contrast between Germany and Ireland and Mexico is apparent, with $100 \%$ of German teachers indicating that they feel confident about teaching sustainability, even before starting the sustainability CPD. The results presented in Table 2 are from participants that completed the surveys in full, partially completed responses were discarded. The pre-program results also demonstrated a gap in knowledge for teachers in Ireland, where none of the teachers reported that they believed they had sufficient knowledge to teach about sustainability.

These represent some of the contextual differences in the starting points of the program. The implementers adjusted, with the Ireland team starting with basic concepts, like the three pillars of sustainability, and the Germany team launching into future-oriented competencies. There was, however, one thread that was consistent in all locations, the interest in sustainability as a form of environmental education. While it is the belief of the authors that sustainability is an interdisciplinary field, focusing on the interconnected concepts of social justice, economic opportunity, mental health, physical health, and inclusion practices, it is clear that respondents entered the program with the environmental focused concepts.

\section{INTERNATIONAL IMPLEMENTATION}

\section{Ireland: Dublin City University}

The first year of the CPD the workshops took place over the course of a six-month period during eight, three-hour evening workshops, in addition to three full days during which substitute cover was provided (which was a challenge to obtain for some). For teachers travelling to the university to participate in the workshops, the after school hours posed challenges in terms of traffic and family commitments. A further challenge identified by the teachers in the first year of the CPD programme was that they felt the CPD was spread out over two academic terms and therefore was disjointed. They recommended that future iterations of the CPD would be rolled out over a shorter period. Considering the challenges identified by the teachers in the first year of the CPD, the second year of the CPD was modified. It was rolled out over a four-month period with fewer gaps between the workshops. The two-day long workshops took place at the weekends rather than during the week, so that substitute leave was no longer an issue, and the time of the evening workshops was changed to suit the teachers. Despite these changes, enrollment declined from 19 participants in the first year to 10 in the second.

With the strong background of the implementers in science education, the content of the CPD focused on developing learners' understanding of the role science plays in addressing societal challenges. Learners were provided with opportunities to reflect on and discuss a range of socio-scientific issues (SSIs), including climate change; renewable energy; choices we make when buying products and the impact of these choices in terms of plastics and pollution. The learners delved into these topics and were encouraged to consider scientific evidence to 
back up their arguments and to be cognisant of different environmental, social and economic factors. The Irish CPD was also focused on supporting teachers in enabling their students to apply and develop scientific knowledge to help them make sense of phenomena they encounter in their everyday lives. Teachers therefore were introduced to inquirybased science education (IBSE) methodologies (Harlen, 2012). See Table 3 (below) for an example of the activities employed. The aim of the collaborative hands-on inquiries and design and make tasks was to afford children with opportunities to apply and develop a range of scientific inquiry, critical thinking and problem-solving skills.

The culminating activity of the CPD was the implementation of a sustainability project within a whole school context. The two teachers per school who participated in the CPD program collaborated to plan and implement the sustainability project in their school. The teachers started planning their schools' projects by participating in a visioning activity that included transformational sustainability goals and links to Taisce's Green School Programme (Ireland's environmental management and award programme, working with primary and secondary schools). Then they proceeded to plan and implement the projects in their schools.
México: Instituto Tecnológico y de Estudios Superiores de Monterrey

The team at ITESM partnered with the coordinator of the environmental agenda of the municipality of Santa Catarina, contacting more than 100 local schools. This collaboration resulted in a very diverse pool of participants including primary and secondary teachers, librarians, as well as city employees. The first edition of the CPD, entitled "Creating Agents of Change Today" was implemented over seven sessions for a total of 60 hours, all of which were held on Saturdays, so that we did not have to cover substitute leave. For the second edition of the CPD, nine sessions were programmed, eight of which were theoretical-practical with a duration of five hours using teaching-learning strategies based on competencies and the ninth session was the community symposium. The extensive recruitment in the Mexico case, as compared to the other locations, can be partially attributed to the partnership with the municipality (although a similar partnership was forged in the Germany location), but also due to the prestige in the community of working with ITESM.

The program started with the teachers learning about the international project, the program objectives, and the background and history of sustainable development addressed from a global and local perspective. Activities consisted of direct instruction, field trips to science laboratories on the

Table 3. Exemplary Pedagogical Activities from Each Country

\begin{tabular}{|c|c|c|}
\hline Ireland & Mexico & Germany \\
\hline $\begin{array}{l}\text { Participants applied IBSE } \\
\text { methodologies when they designed } \\
\text { wind-turbines that will lift a 'load'. } \\
\text { They explored how wind-turbines } \\
\text { work and how wind energy is } \\
\text { transformed into electrical energy. } \\
\text { In groups, they designed a working } \\
\text { model of a wind turbine that } \\
\text { transfers wind energy (using a fan } \\
\text { as a wind source) into mechanical } \\
\text { energy enabling their wind turbine } \\
\text { to lift a 'load'. They considered } \\
\text { different factors that engineers } \\
\text { must be cognizant of when } \\
\text { designing wind turbines. Once they } \\
\text { constructed their wind-turbines, } \\
\text { they investigated what factors } \\
\text { affect how a wind turbine rotates. } \\
\text { This collaborative, hands-on } \\
\text { activity develops a range of inquiry, } \\
\text { critical thinking and problem- } \\
\text { solving skills as well as supporting } \\
\text { them in developing their scientific } \\
\text { content knowledge on energy. }\end{array}$ & $\begin{array}{l}\text { One of the unique features of the } \\
\text { CPD run by ITESM was the } \\
\text { fieldtrips. The "Rompepicos" Dam } \\
\text { was the first stop, after that the } \\
\text { "Huasteca" park located in Santa } \\
\text { Catarina, N.L. was visited. The } \\
\text { objective of these activities was to } \\
\text { have the participants observe, } \\
\text { admire and notice rich natural } \\
\text { places, so they would be more } \\
\text { conscious of the importance of } \\
\text { protecting our environment. } \\
\text { Local field ecologists joined the } \\
\text { team, therefore introducing other } \\
\text { experts and content areas to the } \\
\text { teachers. }\end{array}$ & $\begin{array}{l}\text { The Germany-based teachers connected } \\
\text { strongly with the competence-oriented } \\
\text { approaches due to the long history of } \\
\text { competency-based education in Germany } \\
\text { (de Haan, 2010). In the second session of } \\
\text { the CPD the teachers envisioned a } \\
\text { sustainable school in the future and } \\
\text { developed an image of this school. It } \\
\text { turned out that this vision was central for } \\
\text { the teachers and they regularly drew on } \\
\text { and referred to their experience with that } \\
\text { visioning activity. This activity engaged } \\
\text { with the future-oriented competencies } \\
\text { and strategic action, as it was also the } \\
\text { starting point to back-cast to the present } \\
\text { day and ultimately plan actions to work } \\
\text { today towards the sustainable future they } \\
\text { desire. They presented plans of action to } \\
\text { their schools and created posters that } \\
\text { connected their projects which they } \\
\text { developed and implemented during the } \\
\text { CPD, to their long-term vision. }\end{array}$ \\
\hline
\end{tabular}


ITESM campus, and an introductory activity on nonrenewable and renewable energy. Once the basic concepts were understood, the following three sessions consisted of activities such as carbon footprint calculation; wind-turbine workshops; and lessons with undergraduate students from the Sustainable Development Engineering course on the "Fundamentals for Sustainable Development." During the second year of the CPD, two additional activities were integrated: construction of a smallscale sustainable classroom model and an activity named "Let's go fishing" to teach them about governing the commons.

During the final sessions, the teachers developed action plans to design and implement school-wide projects. Each action plan included a mission, objective, a clear explanation on how their project is going to impart key sustainability competencies, stages and steps to follow for a successful implementation, required material and the estimated impact the project should have. The teachers worked in their teams of 2 or 3 that are at the same school and developed one plan that the GCSO grant supported the material purchasing for. The teachers implemented their projects and presented the outcomes at a community symposium, in the form of poster presentations. The Mayor of Santa Catarina, as well as other political and educational leaders, were in attendance.

\section{Germany: Leuphana University of Luneburg}

The team partnered with the Institute for Quality Development in Schools of Lower Saxony (NLQ) which was responsible for the organization, participation management and making sure that the teachers were officially acknowledged with certificates. The lack of obligatory CPD hours and the intensive nature of this CPD model, resulted in many teachers (and headmasters) feeling the investment of time was too significant. Thus, the team ended up with 9 participants, consisting of teachers, a headmaster (also teaching) and an ESD-coordinator.

The Lower Saxony Education Ministry provided financial support that enabled the team to have a 2,5day retreat for the first session. The retreat was held from Thursday-Saturday as a weekend workshop. The remaining workshops needed to be aligned with school dates and vacation time, which is why the time varied in between the workshops and was sometimes not an ideal timespan. The variety (and high level of engagement) of the group in terms of their roles (teacher, headmaster, coordinator) turned out to be very fruitful in the development of the projects and in the reflections and discussions regarding class and school development and related activities. The high affinity to ecological issues of primary school teachers was the entry point for education for sustainable development and knowledge on which the activities tried to build on, of course also influencing the shape of the professional development. On reflection this affinity was implicitly echoed in the topic or focus of the activities during the CPD (e.g., about the invited experts and excursions).

One of the unique features of the Germany-based CPD was a focus on the theme "food" with problem and solution constellations being built around that theme. With input from the teachers, the LUL CPD aligned the activities, field trips, and planning decisions around this topic. The team intended to make the abstract theory more tangible with a topic that is quite familiar to them, as an integral part of the curriculum, and add new perspectives to it. The thematic decision was also based on the fact that the team recruited especially teachers with "basic science and social sciences" as one of their subjects. Despite intentions, many of the activities and discussions turned out to be strongly problemfocused, rather than addressing a solution-oriented approach. For example, the Fishbone-Diagram was introduced as a tool for problem analyses but due to time constraints the team could not give enough room to explore how this affects the solution development or the evaluation of already existing solutions. Interestingly the very problem-focused approach often used in the introduction of sustainability was reflected at the beginning, but still, once started, the theoretical introduction did not address this intention consistently. Although places and experts to experience sustainability practices in "real life" were chosen, their solutions had not been discussed analytically to carve out how and why these respond to sustainability challenges on different levels and from different perspectives on the problem.

\section{IMPACT ON SUSTAINABILITY TEACHING PRACTICE - TEACHERS' REFLECTIONS \& TEACHERS' ACTIONS}

One of the primary objectives of this project was to understand whether an international model that shares key features can be successfully implemented in diverse contexts. Below we use qualitative results from interviews and open-ended responses to offer insights into the impact of the programme design on the experiences of the teachers. As teachers were expected to have implemented sustainability activities and projects during their time participating in the program, they were able to report concretely from their exploration and implementation processes. Analysis of the teachers' reflections revealed three common issues emerged from the 
intercultural comparison regarding conducting this sustainability CPD:

1) Contact hours sufficient to complete $3 \mathrm{~T}$ model (Transmission, Translation, Transformation) with multiple touch points. One key learning experience that emerged from the international project was the need to develop a program that could vary in terms of frequency, duration, and number of meetings. Finding the sweet spot that enables a program to guide participants through all 3Ts without overdoing it is critical for success. Each location had a different sweet spot that was guided by feedback from teachers and school administrators. The flexibility and responsiveness of our team to the needs and desires of the key stakeholders was central to building long-lasting and positive relationships between the K-12 schools and the universities. Regardless of the exact number of contact hours, having a multi-month duration was critical in achieving school-based change. In interviews teachers regularly commented that it was important to have multiple points of contact over time. A teacher in Germany stated:

"I thought it was very good, that was the best training I've taken part in up till now, because it was very practice-oriented, you had the time to try things out and then also to reflect. Mostly training sessions are just one day or something or maybe a weekend and then you have ideas, maybe tries something out, but you never get together again, so one doesn't have, let's say, the control function is missing a bit at the end and because there were several dates you had a goal, by then I'll have done this, and then you have, let's say, external pressure to really do it and then I think it works a bit better than if you just come back with the ideas and then try to implement them and then you usually lose sight of it somehow in everyday school life, because there's always so much other stuff."

2) Solutions not problems. Content should be something the implementers are familiar with, the participants are interested in, and can be connected to locally. The emphasis throughout the 3Ts model should be on exploring solutions and how to deal with the complexity of sustainability challenges. At the same time this needs a deeper understanding of sustainability and the interconnectedness of social, ecological, political, and economic aspects. Another key method to emphasize solutions is to model solutions in your own operations and planning. Solutions are meant to empower action and to show that teachers are role models not just through the sustainable solutions discussed in class but also through the sustainable solutions they employ in their everyday lives. One teacher in Ireland discussed how this approach impacted her; she stated:

"It questioned my attitude to sustainability and made me more aware of the small measures that I can put in place in my personal life to help and also to give a good example for my pupils."

3) Competencies not content orientation. The learning outcomes for sustainability CPD can be more universal even if the content and context is very different because it is about empowering the teachers with the competencies to transform their schools and communities. Focusing on the competencies enabled teachers to weave sustainability into their own content and context. The aim of the CPD in all three countries was to support teachers so that they would feel confident in their sustainability knowledge and skills so they can continuously grow, adapt, and respond to current events. Through competency development, teachers can develop the requisite confidence and skills to adapt the CPD activities to fit their own contexts and curricula and adjust overtime. As a result of this approach, teachers commented on their more holistic understanding of sustainability. For instance, one teacher in Ireland stated:

"I feel significantly more confident in relation to teaching about sustainability. It has not only given me a better insight into the world of sustainability but has also equipped me with invaluable teaching skills and tools to inform and educate the children about the topic."

The above three points did not operate in isolation, rather they supported each other. We explore solutions but we think about solutions within a complex system (hence using systems thinking). After the CDP, teachers were easily able to talk about these features and how they worked together. One teacher in Ireland stated:

\section{"I found the work on Systems thinking really affected how I approached lessons on sustainability. In lessons we looked at all the knock-on effects of any of our suggested solutions."}

A teacher in Mexico expressed the value of having a deep understanding of sustainability to carry into the future as well as some example curricula to use today. The teacher stated (translated from Spanish):

"I now have a good understanding of the conceptual work and investigations (research) 
on the subject and can bring it to students as a dynamic story, starting with the fun examples."

Another comment of one teacher from Germany touches on sustainability being infused throughout their curriculum, campus, and community. He stated:

"We have also added education for sustainable development to the school development plan in a more target-oriented way and are planning to discuss that with all the staff and also with the school's parent council and to see what projects or activities we could do and there are a lot of ideas from my colleagues and I on what we could do concerning the topic waste or the school garden, yes the experiment room, cooperation with the, eh, what's it called, social eco-village here in X-city or with the gardener's clubs that there are here. We also considered the possibility of working together with the Landvolk, who are happy to come to the school to work on agriculture and products with the children."

Statements such as the one above demonstrates the practice-oriented, implementation-focused direction of this program. The potential impact in the school becomes visible in these reflections.

\section{DISCUSSION}

The findings from this international CPD project highlight the opportunities of working towards a shared framework but call into question the scalability of a lock-step program. The approach taken by this team does have some generalizable, broadly scalable components, such as the $3 \mathrm{~T}$ model, a focus on competencies, the implementation of a school-based project, and a multi-touch program, as compared to the standard one-off CPDs. However, that $3 \mathrm{~T}$ model is most successful when the actual deployment is guided by local feedback, systems, and structures. In this discussion section, we review the key lessons learned regarding impact of $\mathrm{CPD}$, importance of contextual factors, and significant barriers to widespread deployment, in discussion sections A-C.

\section{Substantial Impact}

The purpose behind creating an impactful sustainability CPD is not to educate the teachers per se, but to concretely change the way today's youth are being educated (in a more rapid fashion than the typical work with pre-service teachers). The overview across the three sites demonstrated the impact of supporting school projects developed over the school year with school stakeholders and delving into sustainability beyond the transmission phase to reach a deeper and more dynamic understanding. This points to the importance of one of the design principles: duration and multiple touch points. By lengthening the CPD, teachers experimented with implementation during the program and received support both explicitly (answering questions) to implicitly (a community of support for experimentation). This finding reinforces the research laid out by Desimone (2009), Guskey and Huberman (1995), and Birman et al. (2000), calling for longer duration, multi-session CPD that integrates the learning that happens within the classroom and school. These researchers highlight that through integrating school practices as part of the teacher projects (e.g., composting programs in the cafeteria) and classroom pedagogy (e.g., future visioning led by the teachers with their students), we can have a longer lasting and more systemic impact, as compared to the traditional approach of disseminating ready-to-use curriculum in a one-off program. We want to have an impact on our schools and students through CPD, therefore we need to design and implement programs that follow best practices for achieving this impact, which means going beyond the transmission phase and developing CPD programs that include time for teachers to translate their new knowledge and skills into practice.

\section{Contextual Factors}

Although CPD can provide significant opportunities for teachers to develop self-efficacy (Redman, et al., 2018), implementing a single model for sustainability CPD across contexts proved quite challenging. The education systems, laws, curricula, cultures, etc. are significantly different. Fortunately, this project had several things working in favor of success. Firstly, a model was agreed which was sufficiently universal, and that focused on competencies rather than specific thematic areas. Through a competencies approach, programs can more effectively collaborate and coordinate their efforts, while also supporting the integration of context specific topics. The 3T structure model could also be adapted to very different schedules, implementers, curricula, and cultural contexts, providing an extended CPD experience in line with existing good practice (Murphy, Smith, Varley, \& Razi, 2015; Redman et al., 2018) all while getting the participants more or less to similar places in terms of sustainability project implementation by the end.

One of the key differentiations of this CPD model versus what is typically done is the focus on working with the teachers to translate their learnings and transform their schools. Again, this goes to the development of a model with multiple touchpoints 
and a long duration, rather than a CPD with one faceto-face period, little to no follow-up regarding the implementation process. While this approach was successful, in general, the specifics of how to do it needs to be highly customized for each country and even locality.

\section{Significant Barriers}

While this project identified pathways to success and scaling sustainability CPDs, the barriers to utilizing this as an instrument for societal transformation are significant. Firstly, getting teachers enrolled in long-term, multi-touch CPD programs is a huge challenge. This project was well funded and able to offer much better support both directly and in-directly to teachers than might typically be available, yet, outside of Mexico, significant barriers to teacher recruitment were recognised. While the Mexico-case was boosted by a partnership with the local government, the same approach of partnering with the local government did not work in Germany. It may be that there are no universally successful ways to recruit, rather they need to be highly particularized for the place and time. The type of CPD which we argue is necessary to have a real impact is much harder to fit into the existing systems of CPD and recruit participants for. Teachers have limited hours and are already overburdened, so if there are CPD options that are eighthours in duration, they may be seen as more desirable than longer duration options.

This CPD model seeks to push beyond the norm towards transformational sustainability, based on real-world solutions. From the curriculum, to the teachers, to the implementers, environmental education with its orientation towards traditional natural science and a problem-focus is very challenging to get past, as all three contexts were more or less implemented with a natural science, environmental education bias. The teachers' interest in the pre-program survey, also reinforced this environmental focus. This is a barrier to integrating critical sustainability issues, such as social justice.

Sustainability does not fall into traditional school subjects nor does it have traditional learning objectives. Rather the objectives of sustainability CPD are linked to values, ethical action, and transformative change that goes beyond institutional walls. In all three countries, there is limited institutional support for sustainability education. In Mexico and Ireland there currently are no sustainability-related standards or curricular strands. Until sustainability has a recognized place in the curricula, it will continue to be viewed as an addon, rather than an integral part of education.
Another critical aspect for success seems to be finding the right type of social and institutional support for teachers. What shape this should take is less clear as different types of institutional support had mixed success, and we would argue that further research into school transformations towards sustainability is needed to unravel how CPD can best support this. It is imperative that we explore means by which the barriers to engagement in CPD can be overcome in order to make the most of the power and expertise of in-service teachers (Biasutti, Concina, \& Frate, 2019). This resonates well with insights in different types of ESD teachers and respective competencies (Timm \& Barth, 2021).

\section{CONCLUSION}

Transformative sustainability education is a push from the current trajectory, educational methods, and modes of operating (Frisk \& Larson, 2011; Vare et al., 2019); however, even in an intense, multi-touch CPD, the teachers and CPD leaders struggled to go beyond environmental sustainability as an extension of the initial concepts. Using frameworks, such as the Sustainable Development Goals, did support the expansion of sustainability concepts into more social and economic realms but there is much more that can be done. To get holistic, integrative sustainability concepts into every school and curriculum, there needs to be more institutional support and incentive structures built that afford teachers the time and space to plan for this integration.

While there are numerous logistical and structural challenges to this CPD model, none would seem insurmountable and even in the face of these challenges, we would argue that we need to work harder to collaborate with in-service teachers as such a recognized resource (Biasutti, Concina, \& Frate, 2019). The academy continues to focus its energy on pre-service teachers (e.g. Archambault, Hartwell, Frisk, \& Hale, 2012), while we have shown in this project the substantial potential of sustainability CPD to have impact on our education system immediately. Significantly more research and experimentation is needed to better inform how CPD could better support teachers in doing this. The teachers entered the CPD with very different knowledge and tools to implement ESD. They departed having successfully implemented sustainability curriculum and schoolwide projects. We cannot wait for our future teachers to shape our school institutions, we need to work at all intervention points, including expanding workshops with experienced, in-service teachers.

The model presented here, serves as a framing which we argue should be used as a starting point anywhere. In particular, CPD facilitators can integrate sustainability CPD from many places and 
points-of-view (as ours did from science education or engineering); the key is that by utilizing this model the implementers themselves learn to view the content and topics they are comfortable with through a sustainability, solutions-oriented lens. This is the critical aspect. Despite the potential and universal features of the model there is even more that needs to be carefully and particularly developed for every different implementation. Yet creating effective, transformative sustainability CPDs will be challenging, we argue that it is only if the international community works together that there is any chance for success.

\section{REFERENCES}

Almers, E. (2013). Pathways to action competence for sustainability-Six themes. The Journal of Environmental Education, 44(2), 116-127. https://doi.org/10.1080/00958964.2012.719939

Archambault, L., Hartwell, L., Frisk, E., \& Hale, A. (2012). Developing sustainability literacy among preservice teachers through web-based learning. Society for Information Technology \& Teacher Education International Conference, (1), 83-87. Retrieved from http://www.editlib.org/p/39542/

Biasutti, M., Concina, E., \& Frate, S. (2019). Social sustainability and professional development: Assessing a training course on intercultural education for in-service teachers. Sustainability, 11(5), 1238. https://doi.org/10.3390/su11051238

Birman, B. F., Desimone, L., Porter, A. C., \& Garet, M. S. (2000). Designing professional development that works. Educational leadership, 57(8), 28-33.

Boone, C. (2015). On hope and agency in sustainability: Lessons from Arizona State University. Journal of Sustainability Education, 10(November). Retrieved from

http://search.ebscohost.com/login.aspx?direct=tru $\mathrm{e} \& \mathrm{db}=$ eue $\& A N=111980231 \&$ site $=$ ehost-live

Bryan, A., \& Bracken, M. (2011). Learning to read the World? Teaching and learning about global citizenship and international development in postprimary schools. Irish Aid.

Bürgener, L. \& Barth, M. (2018). Sustainability competencies in teacher education. Making teacher education count in everyday school practice. Journal of Cleaner Production, 174, 821-826.

Darling-Hammond, L., Wei, R., Andree, A., Richardson, N., \& Orphanos, S. (2009). State of the profession: Study measures status of professional development. Journal of Staff Development, 30(2), 42-50. Retrieved from http://eric.ed.gov/?id=EJ832401

de Haan, G. (2006). The BLK 21' programme in Germany: A Gestaltungskompetenz'based model for Education for Sustainable Development. Environmental Education Research, 12(1), 19-32. https://doi.org/10.1080/13504620500526362 de Haan, G. (2010). The development of ESD-related competencies in supportive institutional frameworks. International Review of Education, 56(2), 315-328.

Desimone, L. M. (2009). Improving impact studies of teachers' professional development: Toward better conceptualizations and measures. Educational researcher, 38(3), 181-199. https://doi.org/10.3102/0013189X08331140

Desimone, L. M., Porter, a. C., Garet, M. S., Yoon, K. S., \& Birman, B. F. (2002). Effects of professional development on teachers' instruction: Results from a three-year longitudinal study. Educational Evaluation and Policy Analysis, 24(2), 81-112. https://doi.org/10.3102/01623737024002081

Ferreira, J.-A. A., Ryan, L., \& Tilbury, D. (2006). Wholeschool approaches to sustainability: A review of models for professional development in pre-service teacher education. researchonline.mq.edu.au. Retrieved from https://www.researchonline.mq.edu.au/vital/acces s/services/Download/mq:2015/SOURCE1

Frisk, E., \& Larson, K. L. (2011). Educating for sustainability: Competencies \& practices for transformative action. Journal of Sustainability Education, 2, 1-20. https://doi.org/None.002

Garet, M. S., Porter, A. C., Desimone, L., Birman, B. F., \& Yoon, K. S. (2001). What makes professional development effective? Results from a national sample of teachers. American Educational Research Journal, 38(4), 915-945. https://doi.org/10.3102/00028312038004915

Guskey, T. R., \& Huberman, M. (1995). Professional development in education: New paradigms and practices. Teachers College Press, 1234 Amsterdam Avenue, New York, NY 10027 (paperback: ISBN-08077-3425-X; clothbound: ISBN-0-8077-3426-8).

Harlen, W. (2012). Inquiry in science education. Resources for Implementing Inquiry in Science and Mathematics at School. Retrieved from Http://Fibonacci. Uni-Bayreuth. de/Resources/Resources-for-ImplementingInquiry. Html.

McGarr, O. (2010). Education for sustainable development in technology education in Irish schools: A curriculum analysis. International Journal of Technology and Design Education, 20(3), 317332.

McCormack, O., \& O’Flaherty, J. (2010). An examination of pre-service teachers' attitudes towards the inclusion of development education into Irish postprimary schools. Teaching and teacher education, 26(6), 1332-1339.

Murphy, C., \& Smith, G. (2012). The impact of a curriculum course on pre-service primary teachers' science content knowledge and attitudes towards teaching science. Irish Educational Studies, 31(1), 77-95. 
https://doi.org/10.1080/03323315.2011.634061

Murphy, C. Smith, G. Mallon, B. \& Redman, R. (2020): Teaching about sustainability through inquiry-based science in Irish primary classrooms: the impact of a professional development programme on teacher self-efficacy, competence and pedagogy, Environmental Education Research https://doi.org/10.1080/13504622.2020.1776843

Murphy, C., Smith, G., Varley, J., \& Razl, Ö. (2015). Changing practice: An evaluation of the impact of a nature of science inquiry-based professional development programme on primary teachers. Cogent Education, 2(1). https://doi.org/10.1080/2331186X.2015.1077692

NCCA (2006) Leaving certificate technology syllabus. Ordinary level and Higher level. National Council for Curriculum and Assessment.

Nousheen, A., Zai, S. A. Y., Waseem, M., \& Khan, S. A. (2020). Education for sustainable development (ESD): Effects of sustainability education on preservice teachers' attitude towards sustainable development (SD). Journal of Cleaner Production, 250, 119537. https://doi.org/10.1016/i.jclepro.2019.119537

Plutzer, B. E., Mccaffrey, M., Hannah, A. L., Rosenau, J., Berbeco, M., \& Reid, A. H. (2014). Climate confusion among U.S. teachers. https://doi.org/10.1126/science.aab3907

Popova, A., Evans, D. K., \& Arancibia, V. (2016). Training teachers on the job what works and how to measure it. World Bank Policy Research Working Paper, (September 2016).

Popova, A., Evans, D. K., Breeding, M. E., \& Arancibia, V. (2018). Teacher professional development around the World the gap between evidence and practice, (August), 63.

Redman, E., Wiek, A., \& Redman, A. (2018). Continuing professional development in sustainability education for K-12 teachers: Principles, Programme, applications, Outlook. Journal of Education for Sustainable Development, 12(1), 59-80. https://doi.org/10.1177/2455133318777182

Rogers, E. (2003). Diffusion of innovations. Simon and Schuster. Retrieved from http://books.google.com/books?hl=en\&lr=\&id=v1 ii4QsB7jIC\&oi $=$ fnd\&pg $=$ PR15\&dq $=$ Diffusion + of $+\mathrm{i}$ nnovations\&ots $=$ DJZvsRT190\&sig $=8006 y z N G a 9 E l$ KzF1KKbmRs2D_9Y

Ruane, B., Horgan, K., \& Cremin, P. (1999). The world in the classroom: development education in the primary curriculum. Primary School Development Education Project.

Timm, J.M. \& Barth, M. (2021). Making ESD happen in elementary schools: the role of teachers. Environmental Education Research, 71(1), 50-66.

Vare, P., Arro, G., de Hamer, A., Gobbo, G. Del, de Vries, G., Farioli, F., ... Zachariou, A. (2019). Devising a competence-based training program for educators of sustainable development: Lessons learned.
Sustainability,

11(7), $1-21$. 